\title{
Uncertainty Analysis of Heat Transfer to Supercritical Hydrogen in Cooling Channels
}

\author{
Jutin M. Looke and D, Brian Landrum ${ }^{\dagger}$

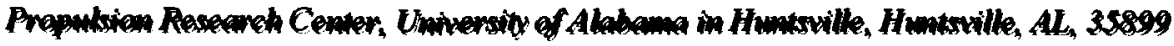

Sound undoritnnding of the cooling efinclency of supercritical hydrogen is cructal to the

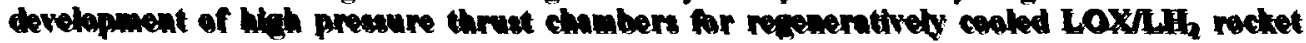
engines. This paper examines historical hent transfor correlations for supereritical hydrogon and the effects of uncertatutice in hydregen property date. It s shown that uncertalinty the to property data alone can be as high as $10 \%$. Previous heated tube experiments with

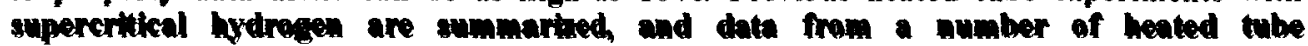
experiments are analyzed to evaluate condition! for which the avallable correlations are ralid

\section{Nomenclature}

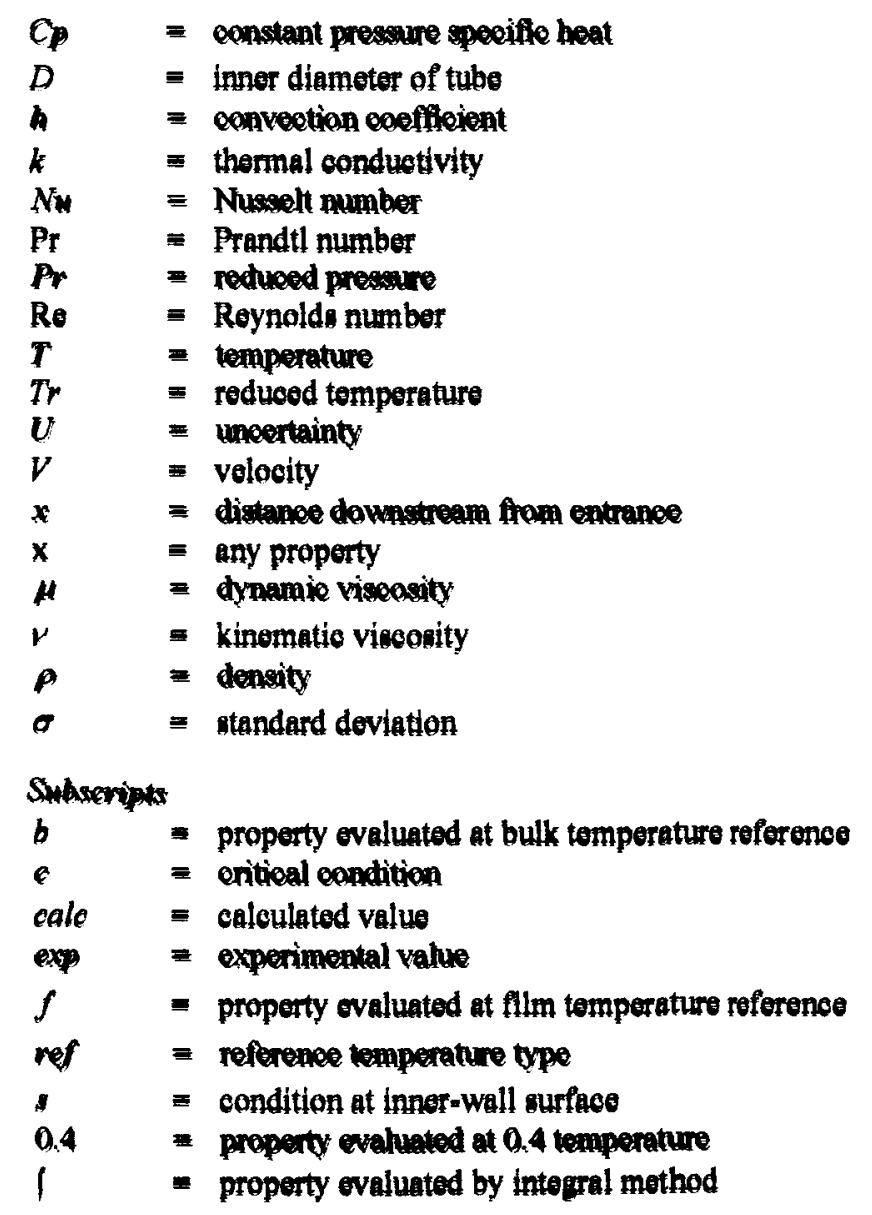

Graduate Reveareh Aeaintant, Momber, AIAA.

${ }^{\dagger}$ Associate Professor of Mechanioal and Aorospace Engineering, Aseociate Fellow AIAA 


\section{Introduction}

A nalytical performance prediction and deaign margin for regeneratively coaled liquid rooket ongines utilize Acorrelation to predict the beat tranafer thom the combuating gas to the thruat chamber wall and from the well into the coaling thuid. These semi-mpinieal heat trenserer correlations are highly dependant on the fluid transport properties and the conditions at which the fluid is flowing. Although a number of coolant-side correlations have been propased for hydregen ating as the ecalant, the ability of the correlations to acourately prediot the heat tranfer over a wide range of operating conditions has typically been limitod.

In addition to the transpart properties heat transer is highly dependent an eooling ohamel geometry. Enforts are ourrently being made to produce aceurate correction factor that can be applied to exiating hont tranefer corrolations to acoun for the ffice of eurvature, roughese aymmetrie beating entrance effects and high aspeet ratio eooling channels for improved thruat ohamber design. For these corroetion factors and now corrolations to have any merit, it is impartant to understand the limitations of these correlation for the simplest ease: a straight unifominy heated, eireular tube. This paper examines existing corrolation for atraight tube geometries using mupororitical hydrogen as the coolant. The uneertainty on the heat tranefer conrelations due to inherent uncertainties in the equation-of-state and tranoport properties of aupereritical hydrogen are evaluated. Provious experimental data is also analyzed with existin published eerrelations over a wide range in the supereritioal region to determine the regions of validity for anch correlation.

\section{Heat Trander Carrolations and Studies}

In typical rocket applisation bydrogen enter the conlant channels as a liquid above the critical presaure (1.3 MPa) and at temperatures an low as $25 \mathrm{~K}$, which is below the erition tomperature of $33 \mathrm{~K}$. High-presenre thruat chambers uning hydrogen as a repenerative coolant operte at very high $\left(>10^{4}\right)$ Reynolds number flow condition in the coolant paseagen' $A$ e the hydregen continues through the channele it is quiekly heated to above the eritical tempereture, where it becomes a supereritioel as shown in Figure 1. The has transfer mecheniems cocurring in these repions are apeseritioal hquid and supereritical foreed convection?

Numerou experimental ctudie heve been performed for hydrogen flowing mupereritioally in uniformly beated eireular tubes. The flow conditions and geometries for many of these tudies are summarized in Table 1. From these atudies most of which toek place in the 1960. came number of carrelations to describe the beat transfor oharateriaties of appereritioal hydrogen in cooling tubes. These corrolations are all principally based on the conventional Nusselt-type equation of Dittus-Boelter, where the Nuselt number is a funotion of the

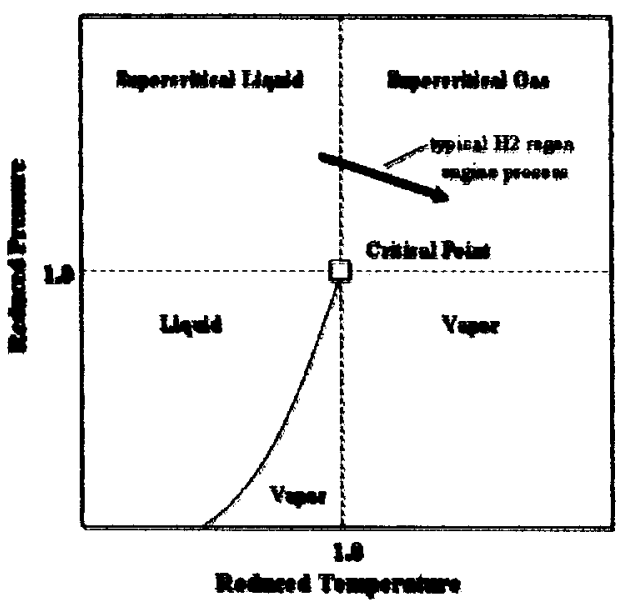

Frare 1: Reduced Preature-Tomporature Diagram Reynolds and Prendtl number ${ }^{3}$

$$
N=0.023 \operatorname{Re}^{20} \mathrm{Pr}^{\mathrm{an}}
$$

In 1960, MeCarthy and Wolf proposed a modifled vernion of this equation, ${ }^{4}$

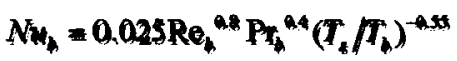

where the subseript $b$ denotes that the properties of ovaluated at the bulk temperature of the fluid and $T_{a} / T_{b}$ is the inner-wall-to-bulk temperature ratio. Hondrioks Simaneau and Friedman in 1955 replaced the bulk condition and proposed the carrelation,"

$$
N u_{f}=0,021 \operatorname{Re}_{f}^{0.9} \mathrm{Pr}_{f}^{0.9}
$$


where the properties are evaluated at the film temperature,

$$
T_{f}=\frac{T_{1} \neq T_{l}}{2}
$$

Hess and Kunz, also in 196, preposed a modified version of the film temperature-type correlation that included wall-to-bulk visoosity ratio,

$$
N u_{f}=0.0208 \mathrm{Re}_{f}^{0.8} \mathrm{Pr}_{f}^{0.4}\left(1+0.01457 r_{t} / v_{b}\right)
$$

Millex, Seader and Trebes (1965) propoed wing a new referenoe temperature, and developed the correlation"

$$
N u_{0.4} \equiv 0.0208\left(\mathrm{Re}_{0,4}\right)^{0.8}\left(\mathrm{Pt}_{0.4}\right)^{0.4}\left(1 \neq 0,00983 v_{s} / v_{b}\right)
$$

where

$$
T_{0.4}=T_{0}+0,4\left(T_{d}-T_{b}\right)
$$

This appraximately constant reference temperature is equivalent to Deissler's camprehensive theary whieh decribes forced convective heat tranofer for turbulent flow at supercritical gas conditions auffioiently above the oritical temperature. The use of bulk temperature physioal preperties with $T_{4} / T_{4}$ eareetien Wolf correlation, has also been shown to be equivalent to the Deisaler theory. ${ }^{2}$

Taylor, working in 1968-1970 in apport of the NERVA and Phoobua-2 nuolear rocket engines, added a correction factor to the MeCarthy \& Wolf correlation to improve the beat tranfor along the length of the tube:-1?

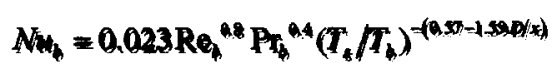

In 1973, Schact and Quentmeyer proposed a now type of reference condition" nueh that,

$$
N m_{r}=0.025 R_{r}^{a n d} P_{r}^{a n}
$$

Thim correlation uses an integral reference type. Property $x$ in evaluatod such that,

$$
\mathrm{X}=\frac{1}{T,=T_{b}} \int_{\mathrm{T}}^{\mathrm{T}} \mathrm{x}(\mathrm{T}) d T
$$

These corrolation have traditionally beon used to caleulate the heat tranefor to oupereritical hydrogen cooling tubes and are all based on the Diturboeltertype equation for $N_{w}$. Ref. 3 provides a goed summary of other laminar and turbulent flow forced convection heat tranefor correlation. Thene correlations may alno be adapted for supeneritieal bydroen tubes. 


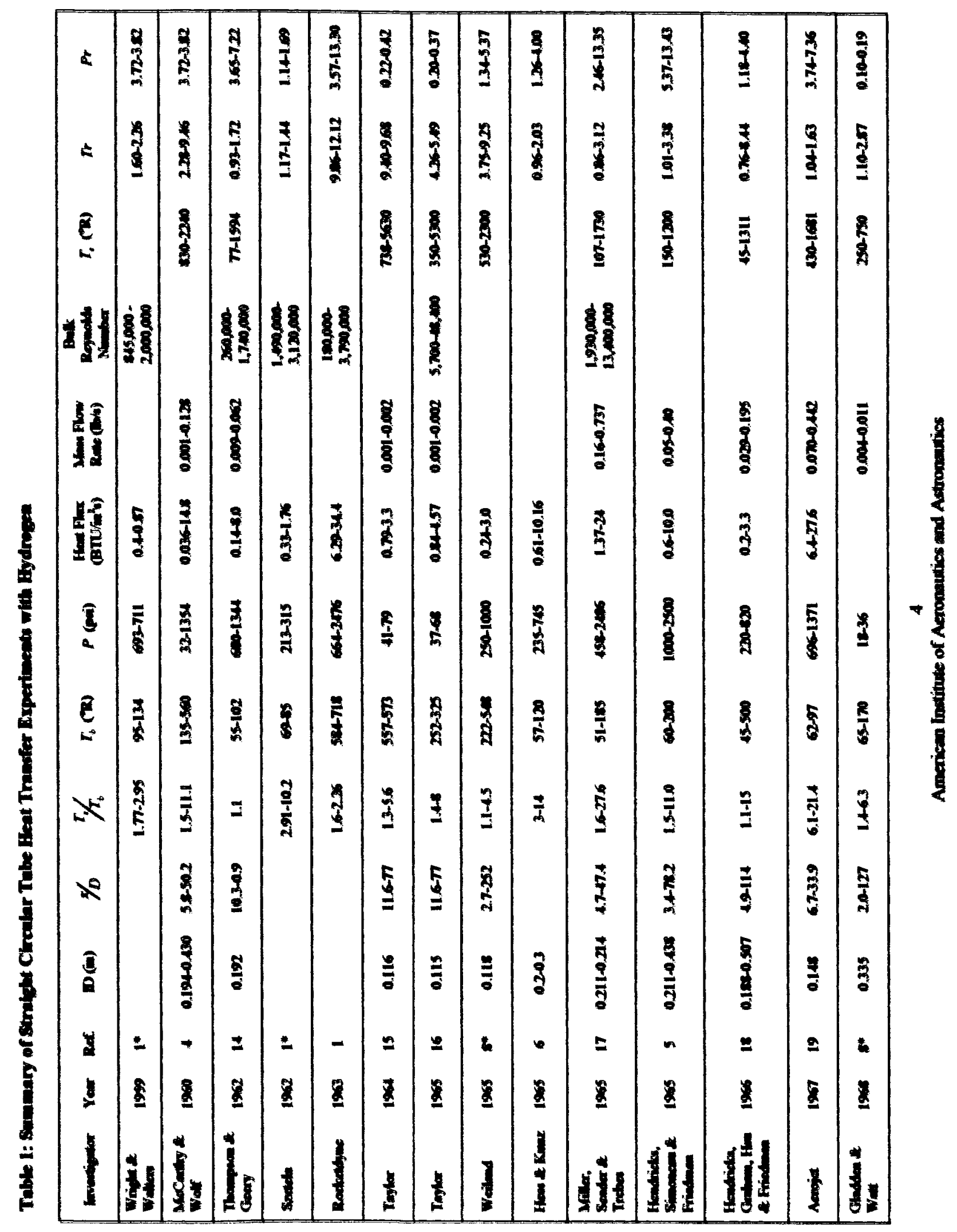




\section{Property Uncerteinty Anglyals}

When conduoting any experiment, the measurements of all variables have uneortainties asaociated with them, as do the vahus of material properties that are abtained though reforenee databases. These uncertaintio preparate throughout the data reduetion equation and produee an overall uncertainty for the caleulated result. For the case of our heat transer analysis the data reduction equations eoneidered are Eq (2) (3) (5), (6) and (8), with

$$
\mathrm{Re}_{w f} \equiv \frac{P_{m} V D}{\mu_{v f}}
$$

and

$$
P_{m f}=\frac{C P_{m} \mu_{m}}{k_{m}}
$$

Where the preperty values are detemined at the reference canditions given by Eqs (4) (7) and (10)

Property valuas for hydrogen were obtained from the NIST Thermadyanic and Trancpart Proparties of Pume

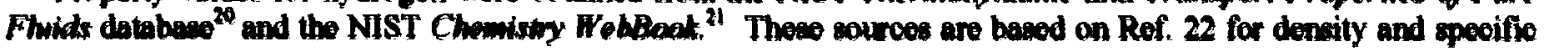
heat, and Ref. 23 for vieonity and thermal conduotivity. They contain data for tomperature up to $400 \mathrm{~K}$. For conditions above 400 K. Ref. 24 was ued, whioh is an updated version of Ref. 25 to concet for emars in certain property data.

The uneertainties bisted in Table 2 are eompiled from thase sapplied by the referenced sourees and are based on accuracies of experimental measurements and inacouracies introduced in fitting the data. The uneertainties quoted are net meent to represent the eritied region where the unoertaintios could reech 10 to 20\% or higher. Indeed an analytical function much as the Modifted Benediot-Webb-Rubin Equation uead by Ref. 22 cannot represent the proper bebavior near the eritioal poin and is not canidered to be valid in that region. For the pupase of this analyais, the uncertainty in the $\mathrm{Nu}$ correlation is not onloulated near the critionl region.

To determine the vold uncerainy in Nu realting from the uncertaintios of each individual property variable a general uncertainty analygis was performod. This was noompliabed by uing a Monte Carlo simulation procram that wes ereated in C*. To perform the Mante Carlo simulation. random errors were seleoted for each variable, based on a uniform parent population with $\sigma$ equal to one-half of the assumed unoertainty for each varibble at the particular tempereture and presaure (as por Table 2). A simulated meacurement was produced by gumming the drawn error with the asamed "true" value of the variable. This was porformod for each variable, and the rosulting $N$ caloulated at the pooifte temperature and prosare. This simulation was repentod 5,000 times at ench temperature and prosare with the realting unoertainty of $N u$ determined twice the ealoulated sample standard deviation The simulation was repated for coob oombination of tempereture and preane within the range of interest. The unoertaintios in experimentally measured variables $(T, P$, etc.) were not

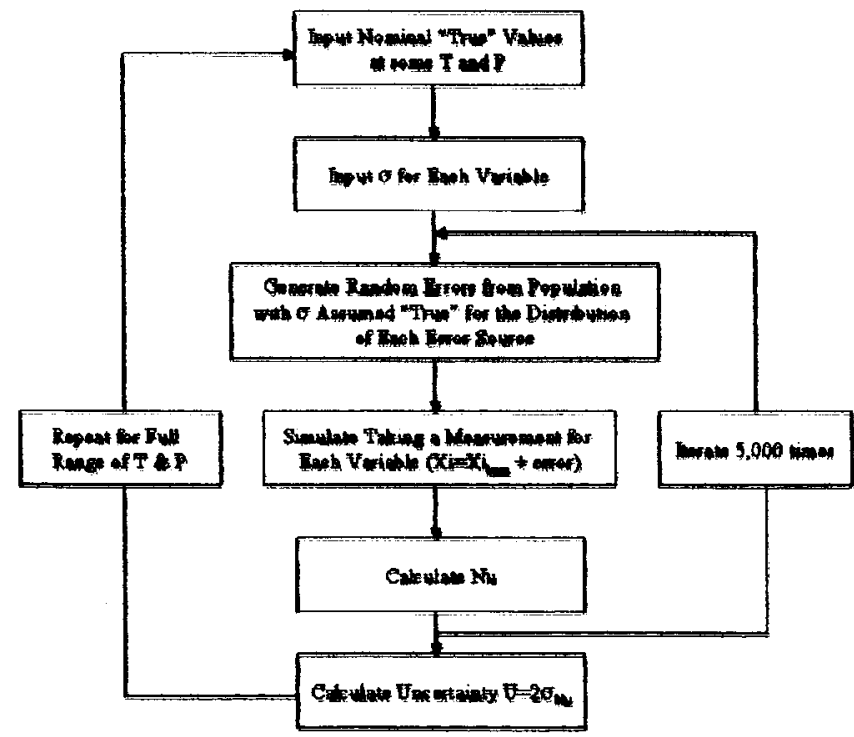

Fhure 2: Flow Chart of Anabya Program and Monte Carb simulation considered bere. 
Table 2: Summary of Property Date. Uneertainty Volues and Sourees Uned th Ambly in

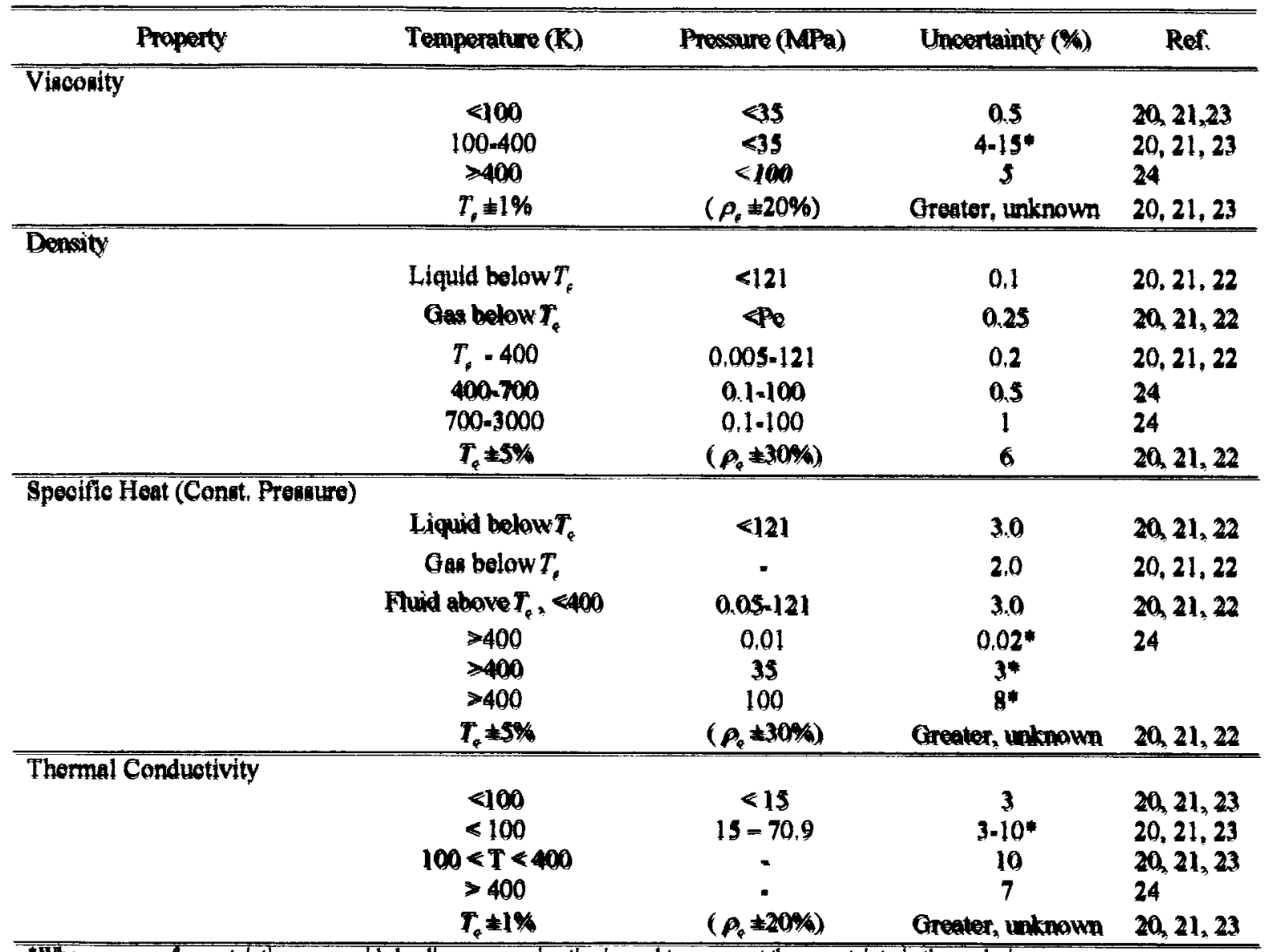

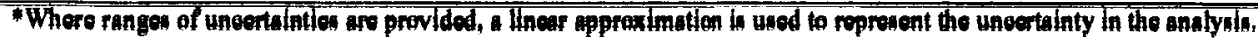

The results of the uneertainty analysis are shawn in Figures 3 and 4 . The blackened region on ench plet is the near critioal region where the uncertainties are not defined. In this region the renultant uncertainty is believod to be highest, but no reasonable extimate exists to quantify it proeisely. As can be seen from the figures the MoCarthy a Wolf and Taylor correlation, both baeed on bulk reference type, produce comparable uncertaintien. The uncertainty is lowest at approximately $1.8 \%$ under the biquid-veper line, $2 \%$ for $T r<3$, and 5 to $7 \%$ for $3<T r<12$. The reduction in uncertainty at $T r>12$ to approximately $4 \%$ in a renult of awitehing the source of property data in this region. The Hentrioks eorrelation shows an uneentainy value of about $5.4 \%$ for $T r<2$, inoreasing to maximum of 7\% at higher tomperatures. The Hens \& Kunz and Miller correlation renults rovoal considerably higher uncortaintien for these carrelations al low prescures and temperatures and alon the liquid-vaper tine. The uneertainty is highest at approximately $10 \%$, and is upwards of 7 to $8 \%$ to $\mathrm{Pr}=2$. For higher temperaturen, the uncertainty is aimilar to that of the Hendrioks errelation at 5 to $7 \%$. 


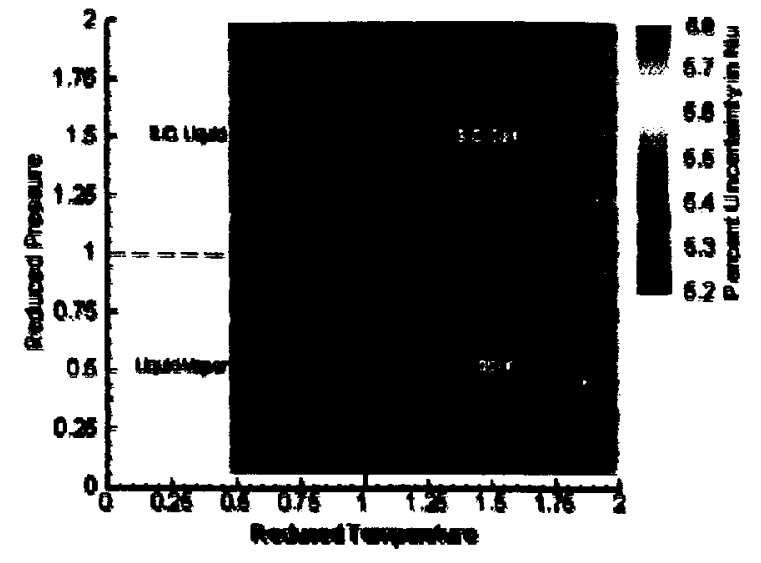

(a) Hondrieks

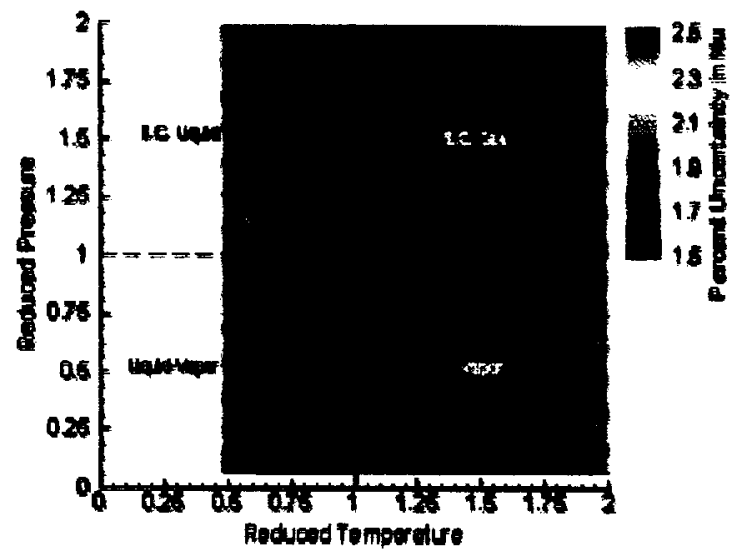

(c) Tarbr

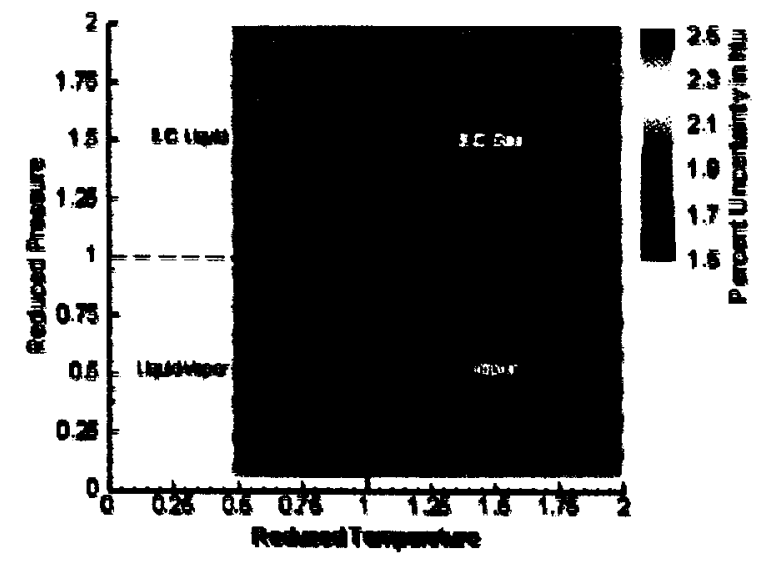

(b) MeCarthy \& Woif

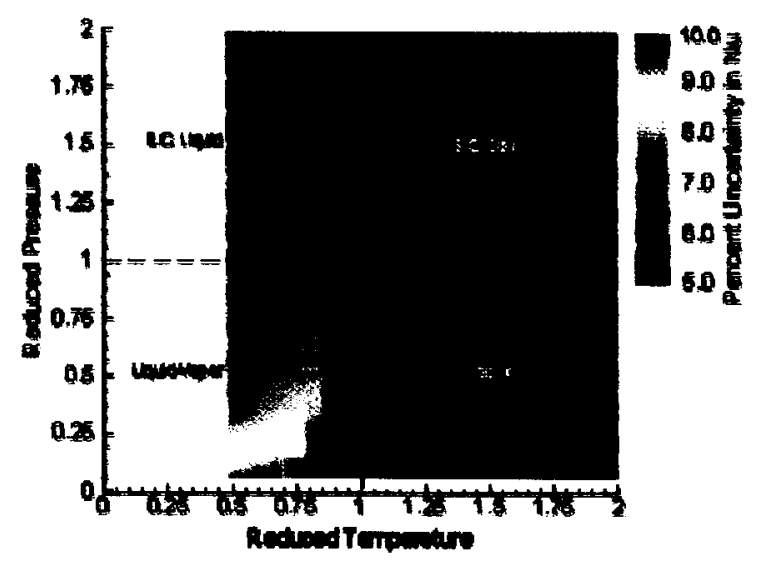

(d) Heas an

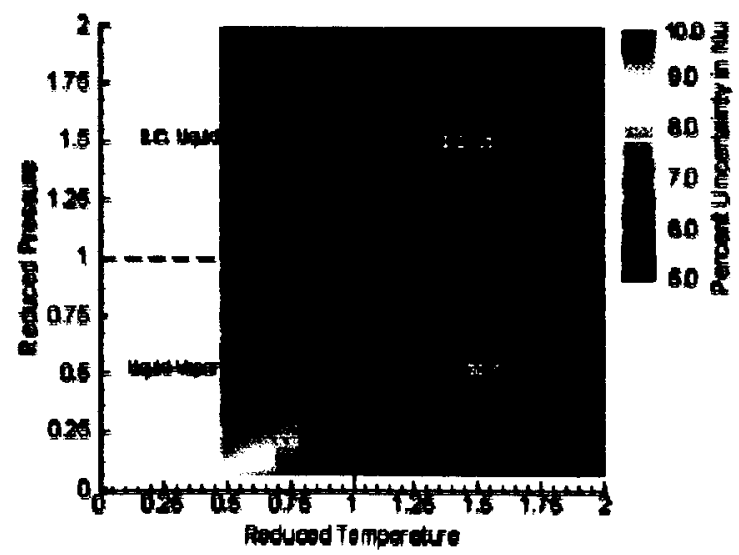

(e) Noiller

Figure 3. Uncertainty Amociated with Nu Near the Critical Region Due to Uncertalnties in Property Datu.

7

American Institute of Aeronautien and Astronauties 


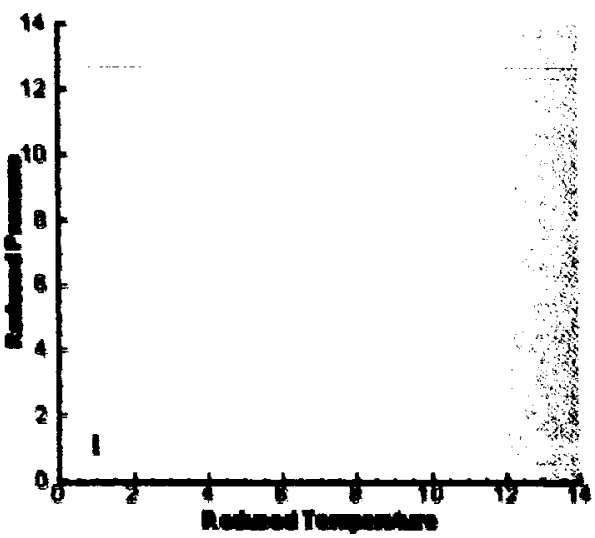

(a) Hendrteks

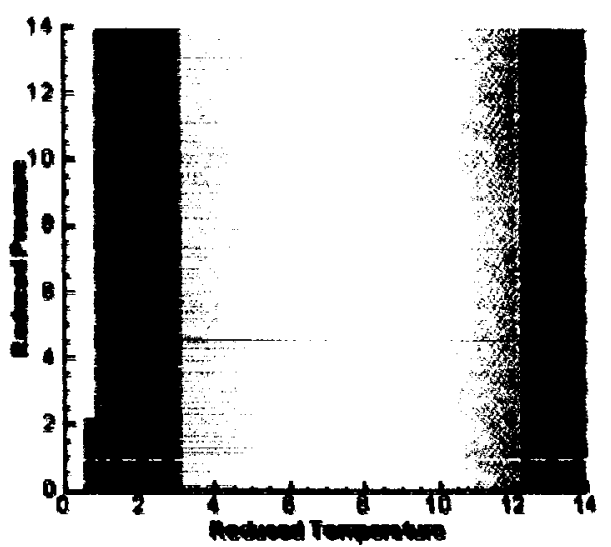

(o) Taylor

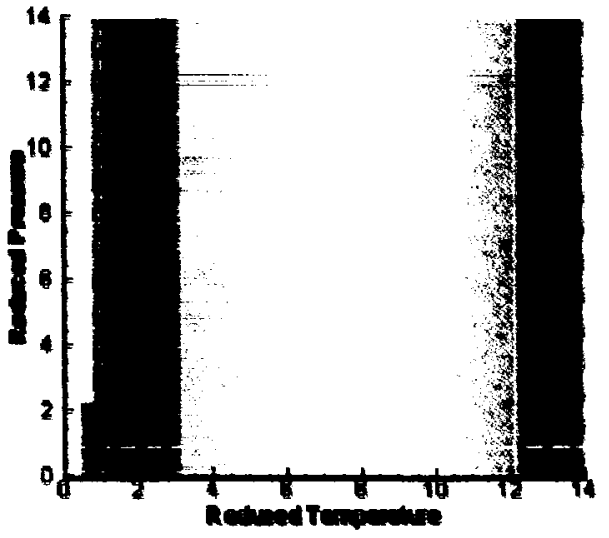

(b) MeCarthy Wole

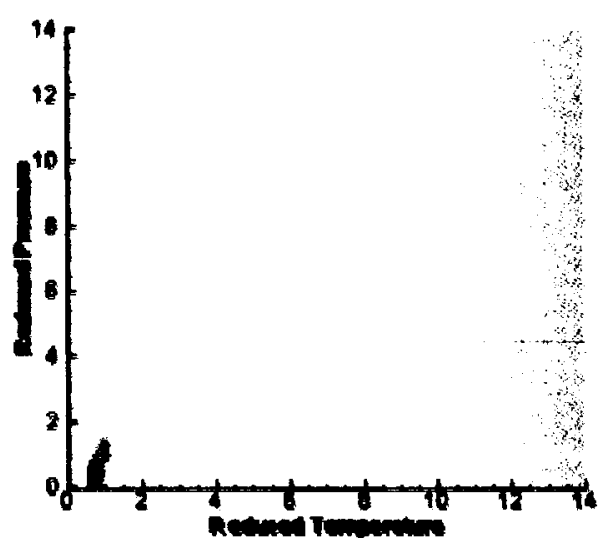

(d) Hoss Kuns
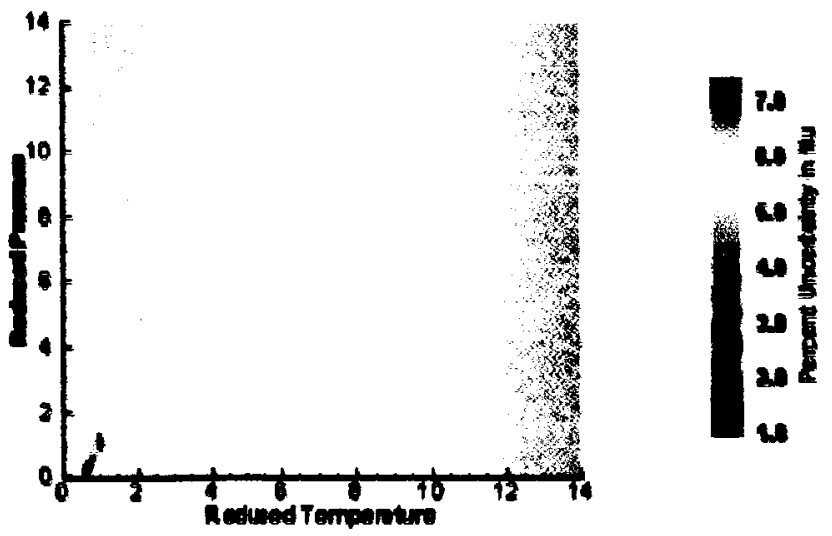

(o) Mink

Figure 4. Uncertainties Assoclated with $\mathrm{Nu}$ in Supercritteal Reglon Due to UncertaIntles in Property Data. 


\section{Expertmented Data Study}

To aneess the ponsible effeets of the property uneertainty, it in uneful to compare experimentally dotermined

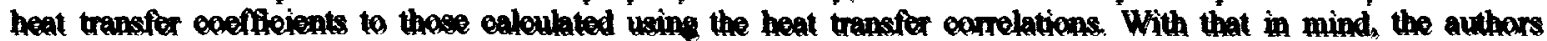
gathered publiahod experimental heat tranofor data for hydrogen in the oupercritioal regimen, and redueed that dat usin mare reont hytroen property dabases.

The dato used in this report ariginate frem experiments conduoted by Hendricks, Simoneau and Friedman (NASA Lewis, 1965), Hendricks Craham, Hsu and Friodman (NASA Lewis, 1966), ${ }^{18}$ and Aerojet-Generel Corporation (1967). ${ }^{19}$ The rangea of condition teated in theo experimental programs ean be found in Table 1 . These saurees were selocted beouse their datasets were readily available, and beouse together they represent a wide range of fluid property conditions. Combined, they represent a total of 2824 data points.

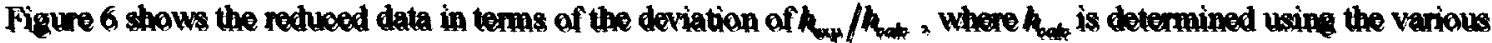
heat tranefor corrolations by the relation.

$$
h_{n+1}=\frac{N u N_{m}}{D}
$$

h. was caloulated by the recpective invertigators at esch paint $h_{w} / h_{-}=1$ represents an exact agreement between predicted and experimental results.

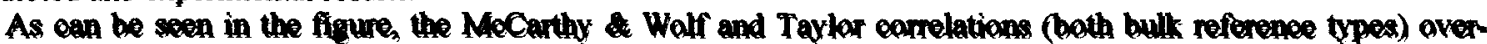
predict the heat transfer in the region elowe to the eritical point. The Hendricks, Heas \& Kunz, Miller and Schact \& Quentmeyer all under prediet in this region.

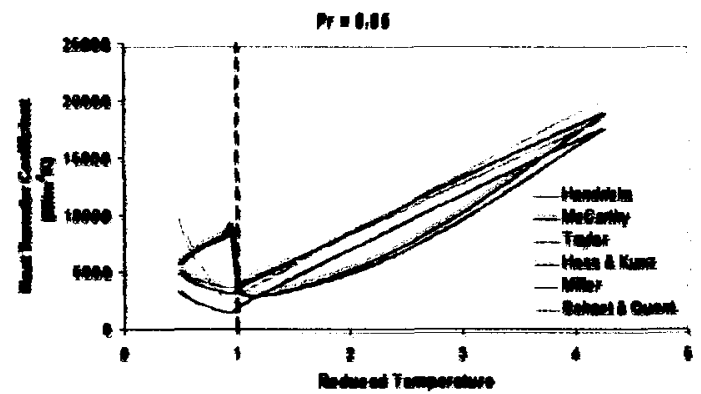

(a)

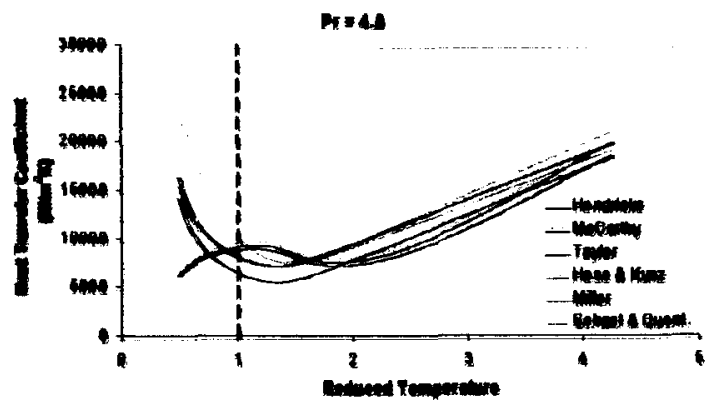

(c)

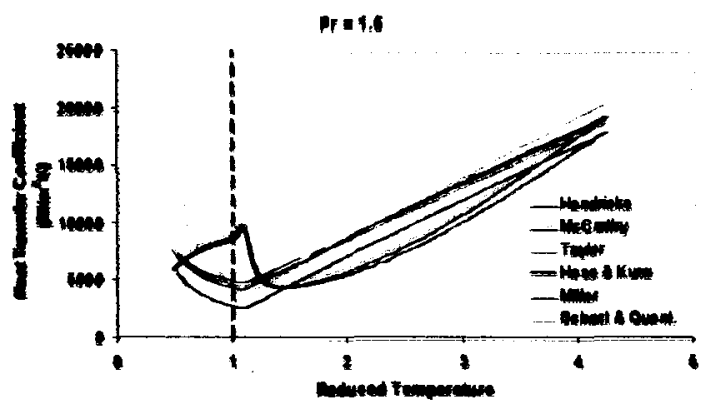

(b)

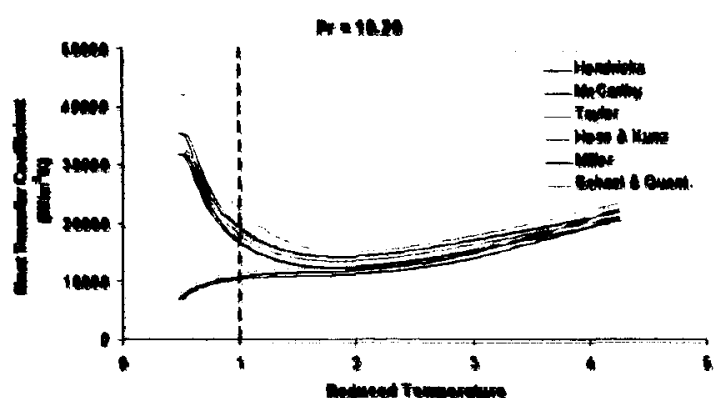

(d)

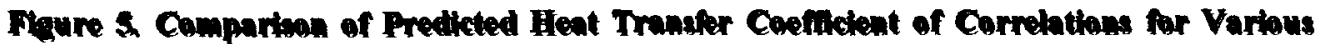
Reduced Preseures, All plots are for $\mathrm{Re}_{k} \equiv 206, T_{1} \equiv 300 \mathrm{~K}, D=0,01 \mathrm{~m}, x / D=40$ : 


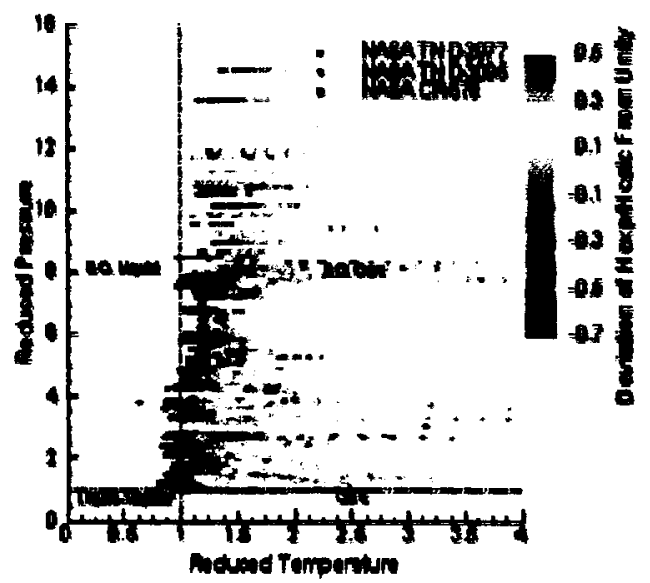

(1) Honltate

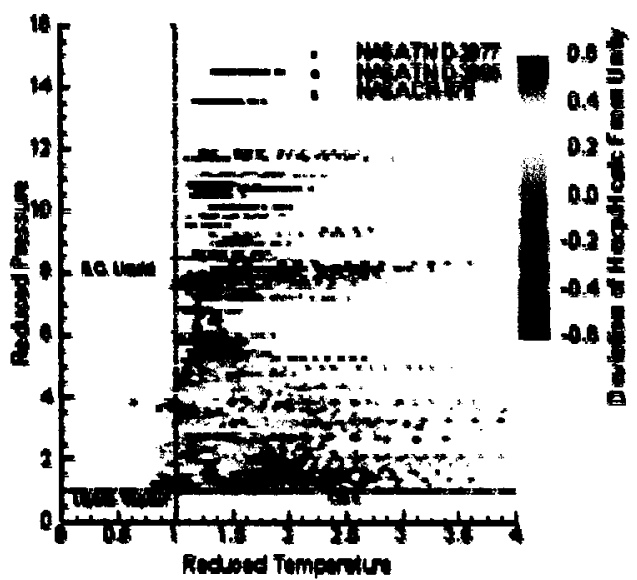

(c) Tapler

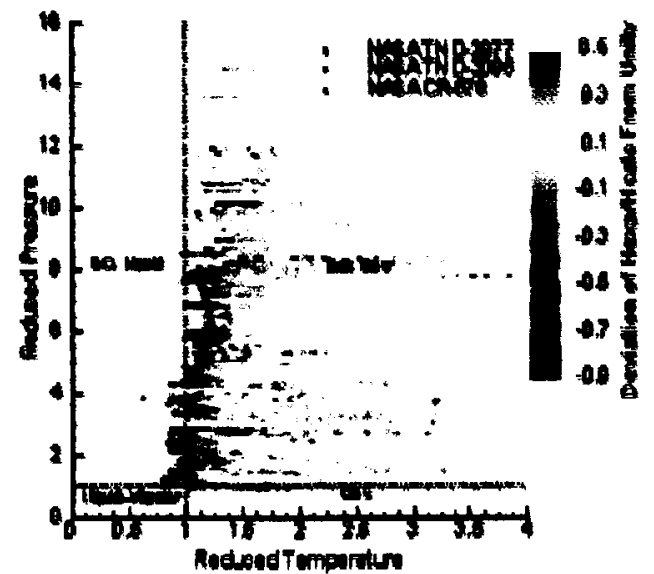

() Matm

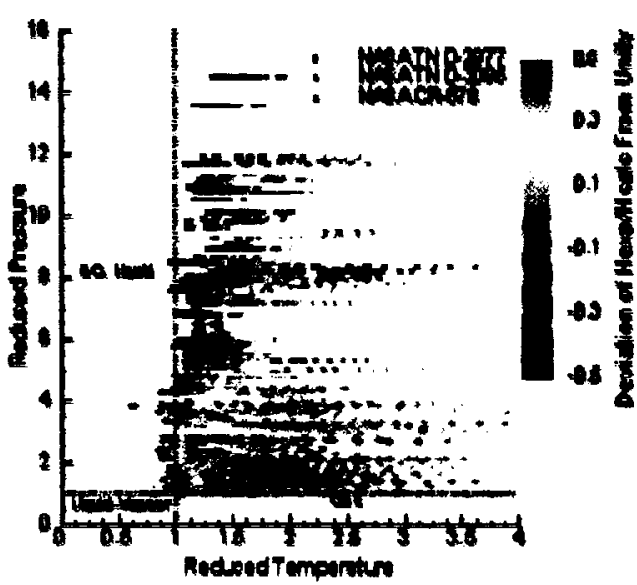

(1) Macorts a wor

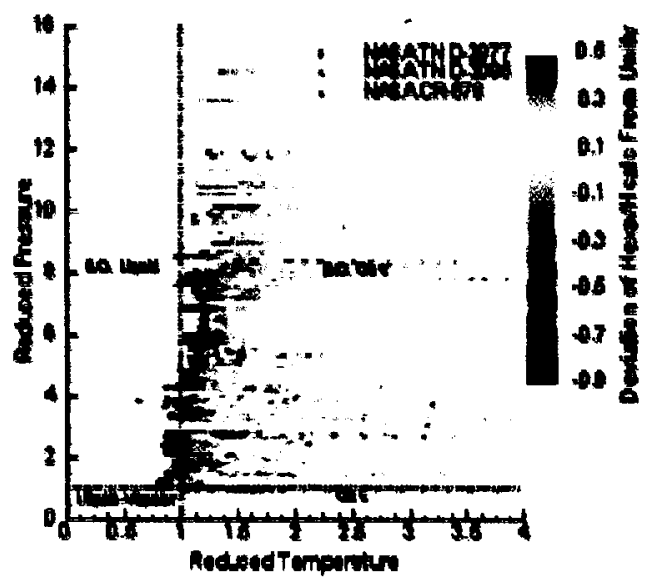

(d) Hess a Kom

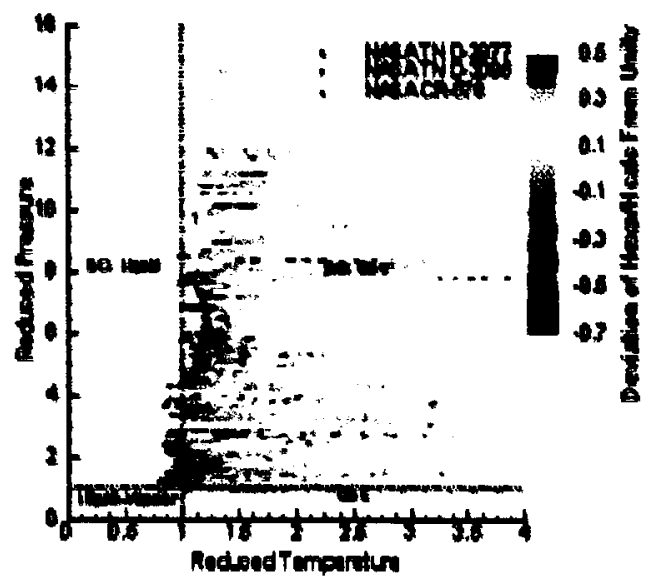

(1) Selast Q Qvontuoper

Figure 6. Deviation of $h_{\text {exp }} / h_{\text {met }}$ from Unity. 
This trend can be seen in a theoretioal comparien of the correlations shown in Figure 5 (b) for reduced preseave equal to 1,6. The apike in the predietion of MeCarthy \& Wolf and Taylor in therefore shown to not reprenent the true conditions in this region.

Aleo from Figure 6, it can bo men that the MeCarthy \&olf and Taylor correlations under-prediet in the region of the line of $T_{r}=1$ for $P r \geqslant 4$. As the presure is inereaced, this range of under predietion extends to larger values of $\operatorname{Tr}$ up to about $\operatorname{Tr}=2$. This can be seen in Figures $S$ (c) and (d) where the trends for MeCarthy \& Wolf and Taylor ben been to diverge inereasing from the other correlations at low temperetures and higher presures. The Schact \& Quentmeyer appears to give the most accurate predietion close to the $\operatorname{Tr}=1$ line for $\operatorname{Pr}<10$.

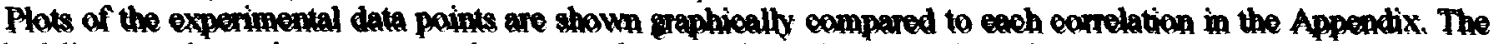
dashed lines on thewe plots represent the range of $\pm 100 \%$ from the prediction of the correlation. From thene plots, along with Figure 6 it is evident that the deviatien of the experimental results them those predioted by the correlations are in many cames conniderably larger than can be explained by the effects of property uncertainty alone.

\section{Canclunions}

1. The uneertainty in Nuselt eorrelations for mupereritioal hydrogen as a result of uneertainty in property data ranges thom $1.81010 \%$

2. The uncertainty on $\mathrm{Nu}$ is affeeted by the roferenee temperature type uned In the low preseure and low temperature range, the bulk reference type conrelations have the lowest uncertainty,

3. The deviation of experimental results to thome predicted by correlation cannot be explained solely by the uncerainy in propery data.

4. The deviations are greatest near the eritioal region and clowe to the transition line $(\operatorname{Tr}=1)$ from liquid to supereritioal for all presure The deviation along the transition line is important for cooling channel applicatione, and an improved correlation ahould be doveloped to better prediet heat tranfer in this region.

5. The best overall fit to the experimental data eame trom the Taylor (Eq. 2) and Solnet Qountmeyer (Eq. 9) correlations. The integral property type of Sohaot \& Quentmeyer is promising, and aubstituting it into other general Nuselt-type equations eould lead to improved conrelations. 


\section{Appendix}
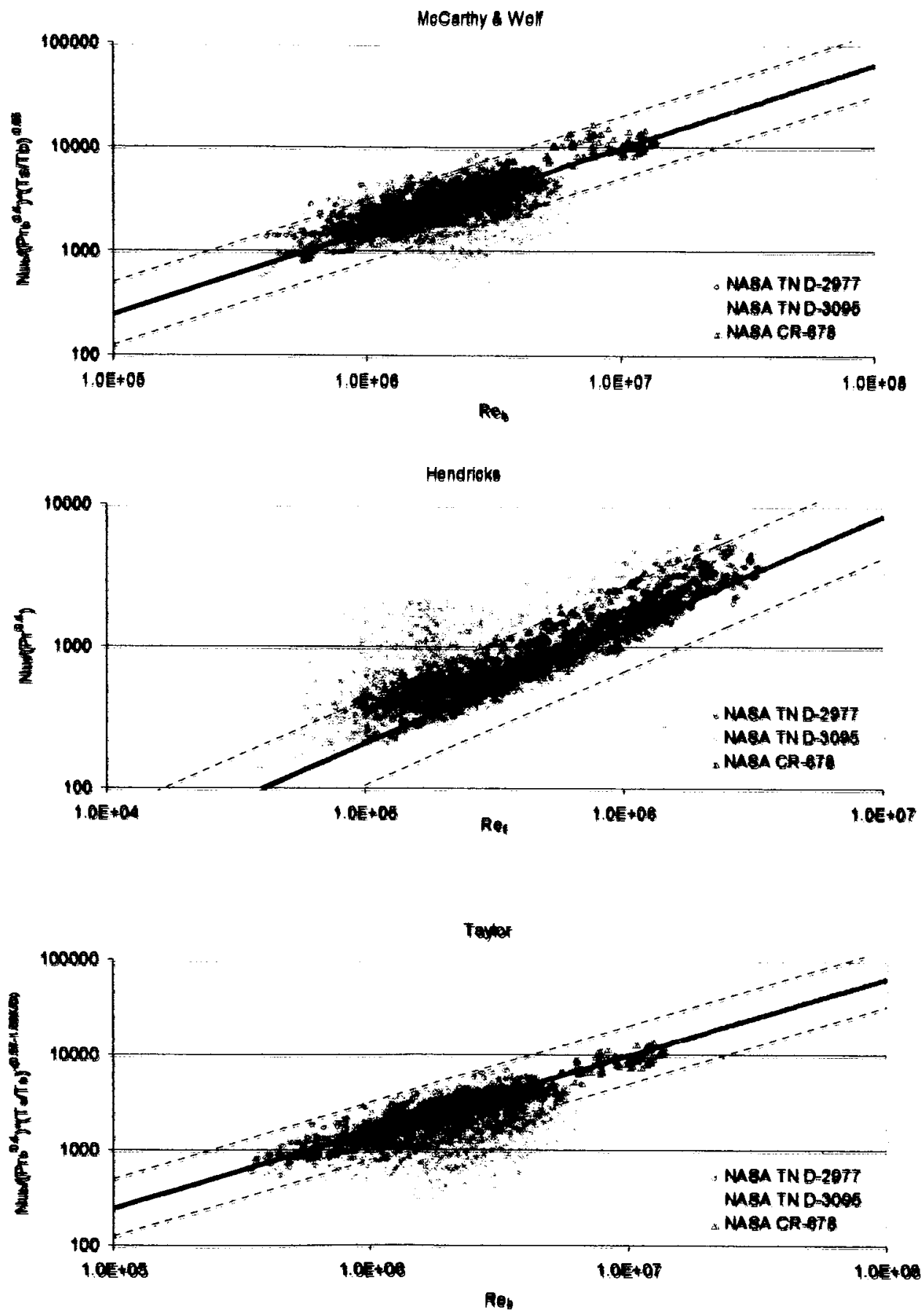

12

American Inotitute of Aoronautien and Astronauties 

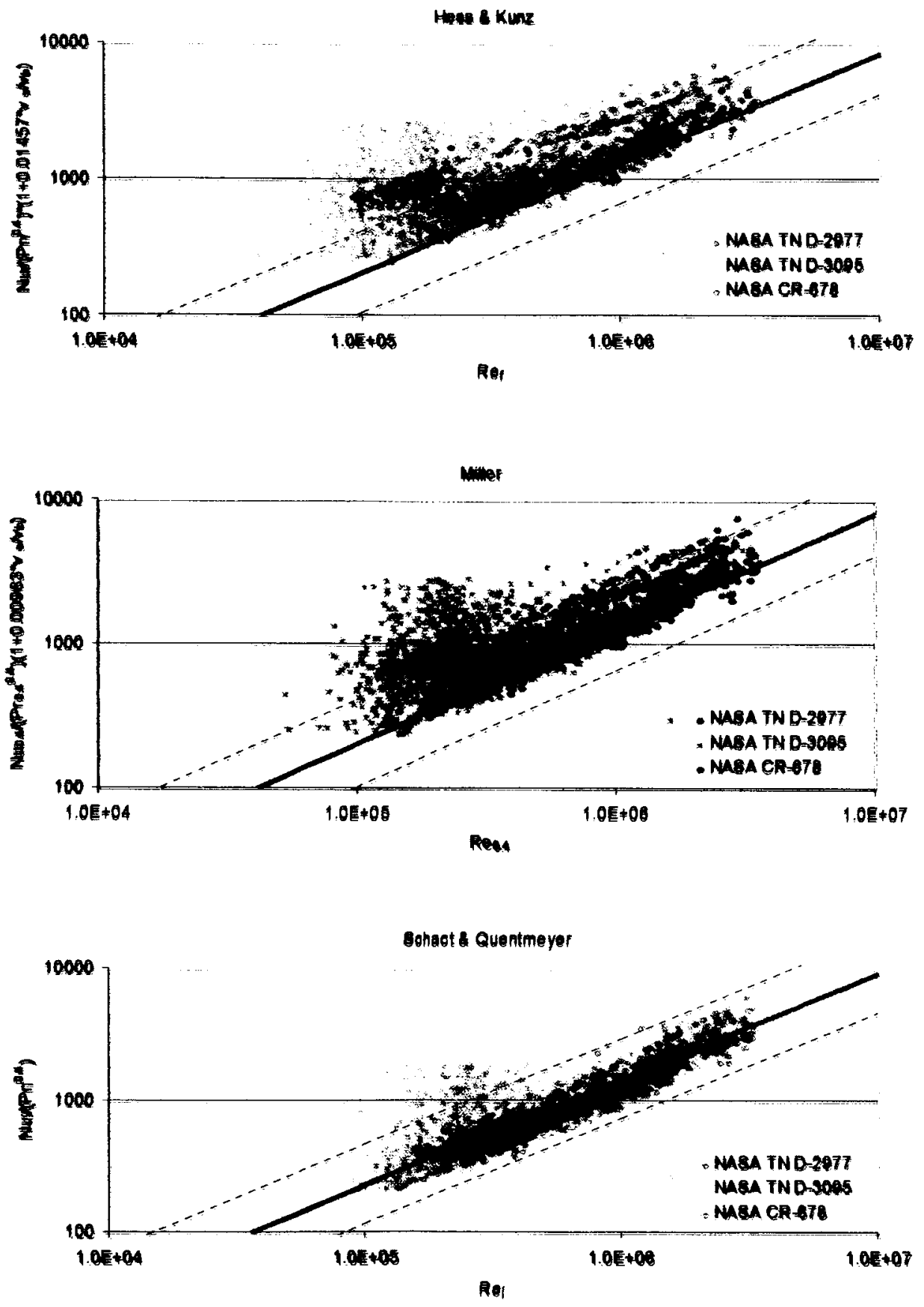


\section{Acknowled mente}

The work reported in this paper was supported by a contraot from the National Aeronautici and Space Administration throug the Condellation University Institures Projeet (CUIP) and the Reoket Engine Advanoement Program (REAP). The authore would like to thank Natalle Walker and Michelle Christeneon for their oupport in compiling the data used in this paper.

\section{References}

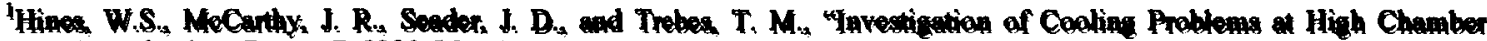

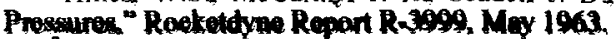

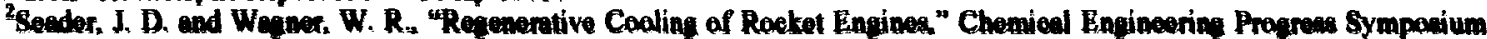
Series 60. No. 52. 1964, pp 130.150.

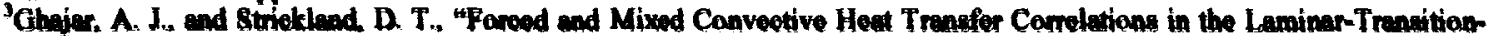
Turbulent Regions for a Cireular Tube with a Square-Edged Entranee," AlAA Paper 1990-1762. Joint Thermophymion and Haat Transfor Conforenoe, sth. Seattlo, WA 1990.

${ }^{4}$ MeCarthy, J. R. and Walf H. "Fareed Convection Heat Tranefor to Geweous Hydrogen at High Heat Fux and High Prosmure in smooth, Round Elestrienlly Hoeted Tubs." ARS Joumel, 30, 1960, pa, 423-424.

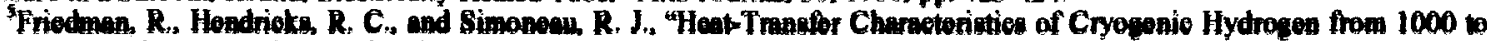
2500 pia Flowing Upwend in Unifomly Heatod Stwigh Tubes" NASA-TN-D-2977. 1965.

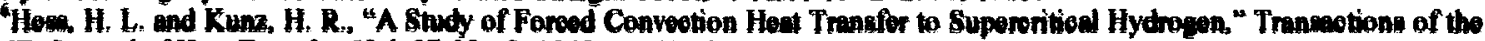
ASME. Journal of Heat Tranier. Vol. 87, No, 2. 1965, pp 41-48.

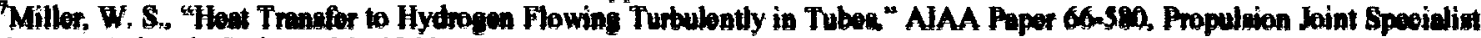
Conferenoe, Colordo Spines CO 1966.

Taylar, M. F," "Correlation of Lood Heat Trenger Cosfioients for Single Phae Turbulent Flow of Hydrogen in Tuben With Temperature Retio to 23" NASA.TN-D4332. 1968.

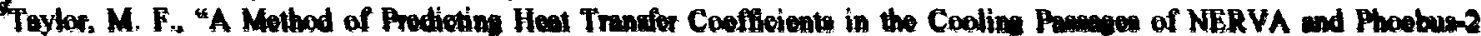

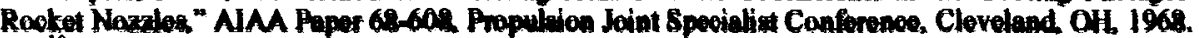

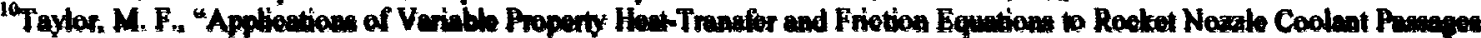
and Comparimon with Nuelor Rooket Tegt Rogults" NASA.TM-X-52793, 1970, Aløo, AIAA Papor 70-661, Propulsion Joint Specieliat Confrence. Sen Diega, CA 1970

"Teyler. M. F." "Summery of Veriable Propenty HeatTrenger Equatione and Their Applieability to a Nuelear Rooket Nozale, NASA-TM-X-52648, 1969

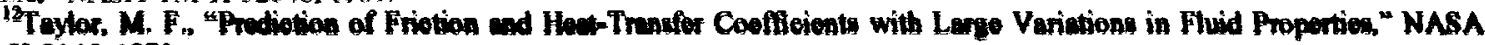
$\mathrm{TM}=\mathbf{X}-2145,1970$

"Sohost, R.L ad Qunnmoyer. R.J. "Coolentside Hon-Tranafor Ratas for Hydrogen-Oxygen Rooket and a New Teohnique for Dat Comdation "NASA TN D-7207, 1973.

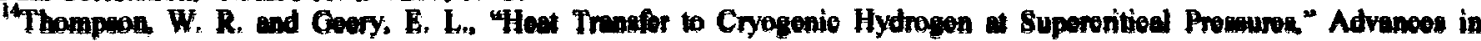
Cryogenie Engineering, 7, 1962. pe, 391-400.

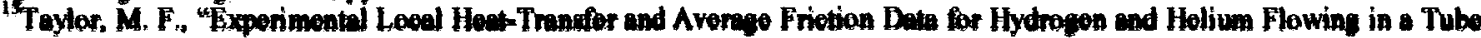
at Surfore Tempenture Up to \$600"." NAM TN D-2080.

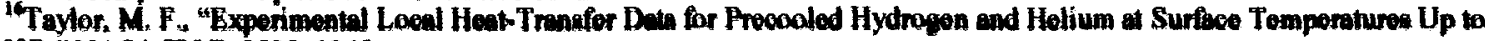
$5300^{2} R^{*}$ NASA TN D 2395,1965 .

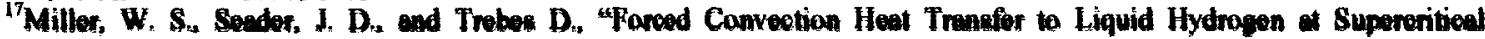

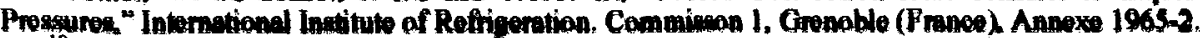

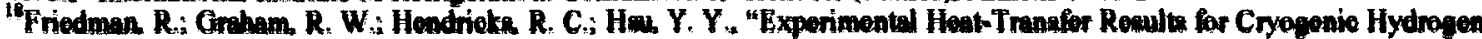

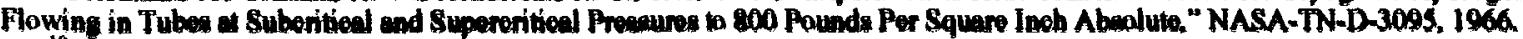

19arojet General Corporation. "Hent Tranfor to Cryogenie Hydrogen Flowing Turbulently in Straigh and Cunved Tubee at High Heet Fluxes" NASA-CR-672 1967.

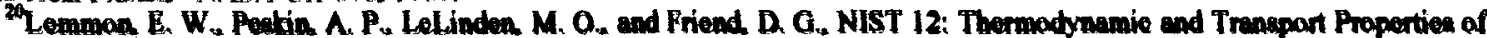
Pure Fluids. Nist Standard Referenoe Database Number 12. Version 5.0, National Inotifute of Standardi and Technology. Bouldex, CO 2000

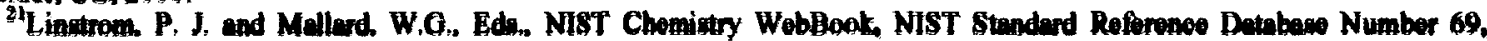

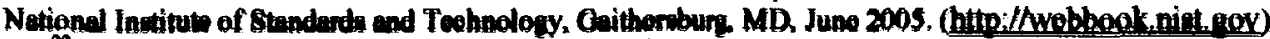

22Younglove. B.A." Thermopinniod Propertien of Fluidn, I, Arean. Ethylene. Perehydrogen Nitrogen. Nitrogen Trifluoride. and Oxyeen" Journal af Phyciod and Chemied Reforence Data Vol. 11, Suppl, 1, 1922

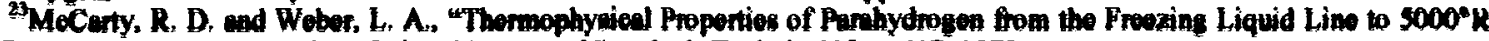

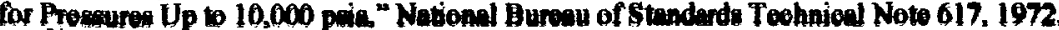

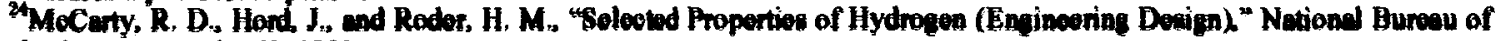
Standarth Monompon 162 1991.

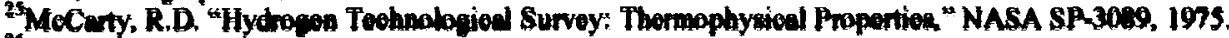

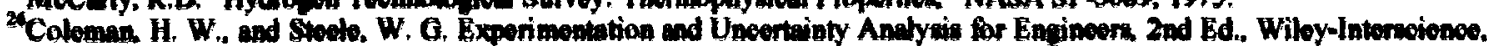
Now York, 1999.

14

Ameriean Inotitute of Aeronautien and Astronautieg 